\title{
住民へのアンケートによる京都市内の街路空間に おける植物栽培の実態調査
}

\author{
Questionnaire Survey of Growing Plants by Neighborhoods around Street Trees in kyoto-city
}

大薮 崇司 ${ }^{*}$ 下村＼cjkstart孝** 小松さち恵**

Takashi OYABU Takashi SHIMOMURA Sachie KOMATSU

\begin{abstract}
The questionnaire was carried out to the residents who are performing flower cultivation in beds of roadside tree in northern kyoto-city, and they were asked about aim of growing plants, evaluation of cultivation, the frequency and kinds of growing management. Consequently, it was shown by the store located in that plants cultivation in the street space in a residential area is positive, or a neighboring business district that the private management person of a store is enjoying plants cultivation. The residents who grow plants in street space announced the plant to a passerby or neighboring residents, and expecting the exchange with people who led plant cultivation was also shown. Furthermore, the questionnaire to a passerby showed that the plant which neighboring residents grew was bearing a wing, which forms the green of a town, and the necessity for the plant cultivation support by administration was suggested.
\end{abstract}

Keywords: roadside tree, passerby, flower cultivation, street space, planting bed キーワード : 街路樹, 歩行者, 草花栽培, 街路空間, 植樹枰

\section{1. 背景と目的}

近年，都市部のほとんどの道路がアスファルトやインターロッ キングなどの素材で舗装されているため, 街路樹の植樹枅は地域 住民に残された貴重な裸地ということができる。この裸地抢よび その周辺を利用している例として, 地域住民による草花や低木な どの植物栽培が挙げられる。このような行為は, 街路樹の根元の 殺風景な空間を華やかに演出すると同時に, 付近に住む人々や歩 行者の目を楽しませる効果が期待できる。花や緑は空間を美しく 飾り, 生活に潤いや安らぎを与えてくれるだけでなく, 植物を栽 培している人（以下, 栽培者) に植物を育てる楽しみをもたらし ていると考えられる。長沼・上甫木 ${ }^{1)}$ は, 神戸市の街路空間にお ける住民による植物栽培を「勝手花壇」と称し, 栽培活動の実態 調査を行うととあに栽培者へのアンケート調査を通じて, 栽培者 同士，栽培者之歩行者，地域住民間に扔いてコミュニケーション が生まれると報告している。篠塚ら ${ }^{2)}$ は, 市街地の鉢植えの緑に ついて, 住宅の形態抢よび栽培樹種より考察を行い, 近隣居住者 間での緑の享受により栽培範囲が拡大していったと推測している。 また, 街路空間での花栽培については, Assenna ${ }^{3)}$ が札幌市を 事例として住民へのアンケート調査を実施し, 花が街路空間に彩 りを提供していることを明らかにしている。京都市の道路区域内 の植樹枡抢よび植物栽培のコンテナなどが置かれている植枰外縁 から $1 \mathrm{~m}$ 内外の限られた空間（以下，植枰周辺）における植物栽 培の実態については, 下村ら ${ }^{4)}$ が通りごとの栽培形態, 樹種, 種 数などを報告している。それによると, 地域住民は, 植樹枰の 18\%において栽培活動を行っていると報告し, また, 植樹枰内之 民地側の植物との比較により, 植枰周辺で植物栽培を行っていた 住民の半数が建物側でも植物を栽培しており, 栽培に関する高い 意欲が植物栽培を街路空間まで拡大していったことが明らかにさ れている。

そこで本研究では, 京都市の様々な用途地域を含む植枰周辺に おける住民による植物栽培に関して，植物栽培を行っている人を
対象としたアンケート調査を行い，栽培目的，植物栽培および街 路空間全般に対する考えを明確にし，住民の植物栽培による街路 空間修景の可能性を探ることとした。また，通行人を想定した回 答者に対してアンケート調查を実施し，栽培者と通行人との間で 街路空間の植物栽培への評価を比較検討した。

\section{2. 研究方法}

調査区域は, 南北通である白川通之堀川通, 東西通である北山 通と今出川通に囲まれた主要な街路空間を設定した（図一 $1^{5)}$; 表- $\left.1^{6,7}\right)$ 。各通りの街路空間に打いて植物栽培が確認された箇 所 ${ }^{4)}$ の前面に位置する住民および店舗経営者を調査対象としてア ンケート調查を実施した。前述の目的に従い, アンケート項目は, 植物栽培の形態, 経歴, 栽培を始めたきっかけ, 植物の入手方法, 管理頻度, 民地での植栽の有無, 街路空間の捉え方, 近隣住民之 の関係，通行人との関係，植物栽培を行う上での不安や期待，植 栽樹種，樹種選定方法など，20 項目とした。アンケート調査は， 対象者を個別で訪問のうえ回答を依頼したが，配布の際，植物栽

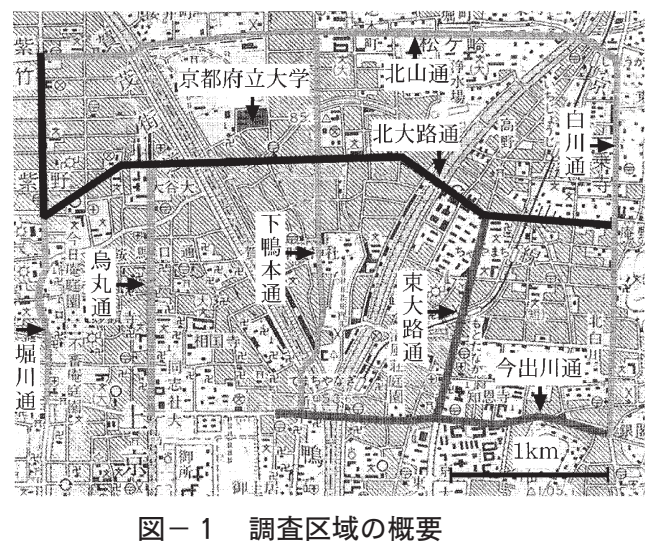

*京都市建設局 $* *$ 京都府立大学人間環境学部 
表 -1 調査路線の植樹枰形態, 緑化延長, 主要植栽樹種, 用途地域および街路樹植栽年

\begin{tabular}{|c|c|c|c|c|c|}
\hline 植樹枅 & 路線名称 & $\begin{array}{c}\text { 緑化延長 } \\
(\mathrm{km})\end{array}$ & 主要植载樹種 & 用途地域 & 街路樹植裁年 \\
\hline \multirow{7}{*}{$\begin{array}{l}\text { 単 } \\
\text { 独 } \\
\text { 㭢 }\end{array}$} & 北山通 & 1.84 & イチョウ & 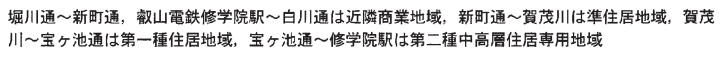 & 昭和30年頃 \\
\hline & 白川通 & 1.21 & イチョウ & 北山通～北大路通は準住居地域，北大路通～今出川通は近䇟商業地域 & 昭和 30 年䪸 \\
\hline & 烏丸通 & 0.80 & イチョウ & 北大路通〜紫明通は近隣商業地域, 紫明通〜今出川通は商業地域, ただし一部が第一種住居地域 & 明治45年頃 \\
\hline & 今出川通 & 1.05 & ススカカケノキ, イチョウ & $\begin{array}{l}\text { 寺町通〜白川通は近隣商業地域，例外として川端通〜東大路通の一部は淮住居地域，東大路通〜白 } \\
\text { 川通の一部は第一㮔中高層住居尃用地域 }\end{array}$ & 大正12年頃 \\
\hline & 下鴨本通(北大路通～今出川通) & 0.85 & イチョウ & 北大路通〜松ヶ崎通は近隣商業地域，松ヶ崎通〜葵橋は準住居地域，葵橋〜今出川通は商業地域 & 昭和30年頃 \\
\hline & 堀川通(北山通〜紫明通) & 0.64 & イチョウ，アオギリ，ケヤキ(中央分離帯) & 北山通〜紫明通は準住居地域 & 昭和 8 年頃 \\
\hline & $\begin{array}{l}\text { 北大路通 } \\
\text { (鳥丸通〜鴨川,東大路通〜白川通) }\end{array}$ & 0.53 & トウカエデ & 鳥丸通〜鴨川は商業地域，東大路通〜白川通の間は準住居地域 & 昭和 5 年頃 \\
\hline \multirow{4}{*}{$\begin{array}{l}\text { 連 } \\
\text { 続 } \\
\text { 材 }\end{array}$} & 東大路通 & 0.68 & スズカケノキ, イチョウ, アベリア, ヒラドツツジ & 近㴹商業地域 & 大正10年頃 \\
\hline & 下鸭本本通(北山通～北大路通) & 0.41 & トウカエデ, シャリンパイ, キンモクセイ, ニシキキ & 第二種中高層住居専用地域 & 昭和30年頃 \\
\hline & 堀川通(紫明通～今出川通） & 0.40 & イチョウ，シャリンバイ，ヶヤキ(中央分離帯) & 紫明通〜鞍馬口通は準住居地域，鞍馬口通〜今出川通は商業地域 & 昭和 8年頃 \\
\hline & $\begin{array}{l}\text { 北大路通 } \\
\text { (堀川通 鳥丸通,䲧川 東大路通) }\end{array}$ & 1.30 & トウカエデ, アベリア, シャリンバイ & 堀川通～烏丸通は近隣商業地域，鴨川 東大路通は近隣商業地域 & 昭和 5 年頃 \\
\hline
\end{tabular}

街路樹植载年については，植载が始まったとされる年を記载した。また，戦災による延焼防止のために撤去され，戦後市街整備計画で復旧され，現在に至っている路線もある。

培を行っている当事者ではないと判明した場合, 実際の栽培者を 捜し出しアンケートを依頼した。配付は，2001年 12 月 12 日に 行い, 2001 年 12 月 18 日に回収した。

また, 通行人としては, 通学や日常生活で周辺道路を使用して いる京都府立大学学生と生涯学習受講者を対象とした。街路空間 での栽培活動をどのように捉えているかに関する 8 項目のアンケー 卜調查を行った。30 歳代〜 50 歳代の回答者の比率が低かったた め, やや片寄りのある結果となったことは否めないが, 一定の傾 向は示されたものと考える。

\section{3．植物栽培者を対象としたアンケート結果 \\ （1）栽培者の基本情報}

植物栽培の行われていた箇所の前面住宅抢よび店舗を回り 558 部のアンケートを配布した。有効回答数は, 202 部（回収率 $36 \%$ ）であった（表－2）。回答者 202 人の属性は, 女性 136 人 に対して男性 41 人之女性の割合がかなり高くなっていた。年齢 は, 60 歳代が 51 人 (25\%) で最多く, 次いで 50 歳代 47 人 (23\%)，70 歳代以上 41 人（20\%）となっていた。職業について は, 自営業主・家族従業員之答えた人が 108 人 (53\%) と半数を 超え, 主婦・無職が 51 人 $(25 \%)$, 会社員・公務員が 10 人（ 5 \%), 嘱託・パート・アルバイトが 10 人（ $5 \%$ ）であった。

\section{（2）植物栽培に関する意識全般について}

植物を栽培することについて，「好きである」とした回答者は， 169 人（84\%）であった。街路空間で植物栽培をしている人は, 基本的に植物栽培自体が好きな人であるということが判明した。 しかし，「好きではない」と答えた人も 5 人（ $3 \% ）$ 見受けられ た。また, 街路空間以外で植物栽培を行っていた回答者が 171 人 (85\%) 認められ，その内 93 人（54\%）が「玄関前・入口前」, 73 人 $(42 \%)$ が「室内 (店内) 」, 69 人 (40\%) が「庭」, 60 人 （34\%）が「ベランダ」と回答した。その他の回答としては, 屋 上が 10 人，畑が 2 人，軒下が 1 人などであった。この結果は， 街路空間で植物栽培を行っていた回答者の多くが, 他の場所で栽 培できない代償として街路空間で植物栽培を始めたのではないこ とを示唆しているあのと考えられた。日本では, 庭のある場合, 基本的に門外に植物を置くことはなく, 庭がないときに限り, 門 外・玄関前に植物を配してきたと言われてきたが，戸建て住宅団 地の出現とともに庭があっても門外に植物を配する傾向が見受け

\section{表－２＼cjkstart回答者の性別と年代}

\begin{tabular}{|c|c|c|c|c|c|c|c|c|c|}
\hline 年秢層 & 20 代 & 30 代 & 40代 & 50 代 & 60代 & 70代以上 & どちらも & 無回答 & $\overline{\mathrm{at}}$ \\
\hline 男性 & $542 \%$ & $433 \%$ & $732 \%$ & $\begin{array}{ll}6 & 13 \%\end{array}$ & $12 \quad 24 \%$ & $717 \%$ & $\begin{array}{ll}0 & 0 \%\end{array}$ & $0 \quad 0 \%$ & 41 \\
\hline 女性 & $758 \%$ & $8 \quad 67 \%$ & $1568 \%$ & $3983 \%$ & $3365 \%$ & $2971 \%$ & $240 \%$ & $325 \%$ & 136 \\
\hline どちらも & $0 \quad 0 \%$ & $0 \quad 0 \%$ & $0 \quad 0 \%$ & $12 \%$ & $12 \%$ & $0 \quad 0 \%$ & $360 \%$ & $0 \quad 0 \%$ & 5 \\
\hline 無回答 & $0 \%$ & $0 \%$ & $0 \%$ & $2 \%$ & $5 \quad 10 \%$ & $5 \quad 12 \%$ & $0 \quad 0 \%$ & $975 \%$ & 20 \\
\hline it & $12100 \%$ & $12100 \%$ & $22100 \%$ & $47100 \%$ & $51100 \%$ & $41100 \%$ & $5100 \%$ & $12100 \%$ & 202 \\
\hline
\end{tabular}

られるようになってきたとの報告 ${ }^{8}$ がある。この考えに従うと今 回の結果は，植栽場所を建築敷地のみから街路空間にまで拡大し て考えるようになってきたことを示唆していると思われた。街路 空間で植物栽培を行う人の多くは，建築敷地で植物栽培を楽しむ 傍ら, 街路空間でも植物栽培を行っていると考えられた。

（3）街路空間での植物栽培について

街路空間で植物栽培を始めた時期については，具体的に年号で 回答があったもののみを集計し，有効回答数を 154 人とした。開 始年度を比較したところ，2000 年に栽培を始めた回答者が 16 人 (10.4\%)，2001 年に栽培を始めた回答者が 14 人（9.1\%）と， 2000 年以降に植物栽培を始めた人が比較的多いことが判明した。 1990 年以降に植物栽培を始めた回答者は, 105 人 (68.2\%) となっ た。高橋・下村 ${ }^{9}$ によるグリーンアドバイザーへのアンケート調 查によると，ガーデニングブームの始まった時期として，大阪で 花博の行われた 1990 年を挙げる人が最む多かった。このガーデ ニングブームによって, 植物栽培に興味を持ち, 街路空間にまで 植物栽培を拡げていった人が多いのではないかと推測された。ま た，通りごとに見ると，鳥丸通では，東側・西側ともに，1990 年より以前から植物栽培を行っていた回答者が 6 割を超えていた (図一2)。これは, 烏丸通が京都駅から御所までの御幸通として, 京都における最初の街路樹が整備され，明治 45 年には花が大き く目立つユリノキが植栽されていたことも影響していると思われ た。さらに，鳥丸通沿いは近隣商業地域となって打り，比較的古 くから受継がれてきた店舗・店舗兼住宅が軒を連称，人の入れ代 わりも余り無かったため, 永続的に街路空間で植物栽培を行うこ とが可能だったと考えられた。反対に, 北山通のように, 近年, 急速に開発されてきた通りは，ここ数年で栽培を始めたという回 答者が多く見受けられた。

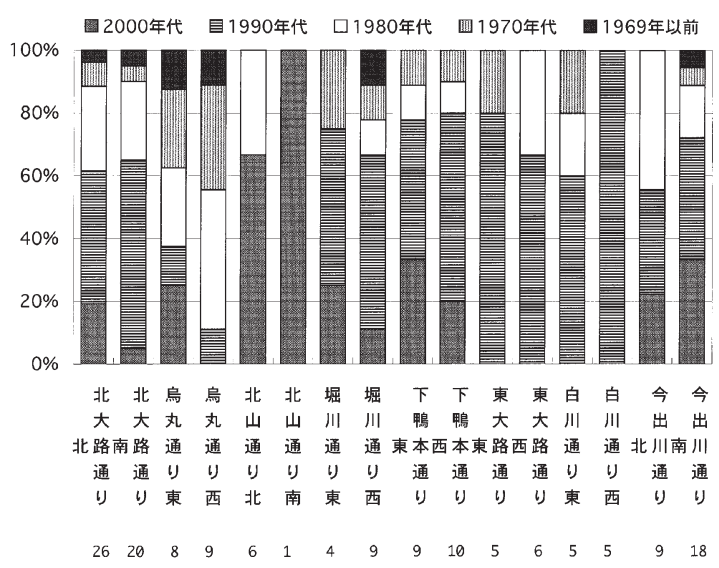

図ー2 路線ごとの栽培開始年 $(N=154 ;$;ただし 4 名は路線名未記載 $)$ 
街路空間で植物栽培を始めた理由・きっかけを図ー 3 に示した。 「街路空間が殺風景であったから」とした回答者が 91 人（47\%） と最む多く, 約半数の回答者が行政が整備した単調な街路空間に 物足りなさを感じていたと考えられた。次いで,「ほかの場所に 比べ日当たりが良かったため」が 76 人 (39\%),「自宅（店舗） に充分な栽培スペースがなかったため」が 66 人 (34\%) 之，他 の空間で植物栽培を充分に楽しむことができない代償として街路 空間を利用し始めたという回答者屯多く存在したことが明らかと なった。その他の理由として,「ほかの人が栽培しているのを見 て影響を受けて」,「近所の人や通る人とのコミュニケーションを 楽しむため」が共に 48 人 (23\%), 「自分の育てた植物を多くの 人に見てもらうため」が 42 人 (22\%)，「住まいまたは店舗のイ メージアップのため」が 41 人（21\%)，「ただ植物を植えたかっ たから」が 36 人 (18\%) という結果であった。他の栽培者の影 響を受けて植物栽培を始めた回答者が 2 割程度であるが存在した ことから, 今後も新たに植物栽培を始める人が出現するものと予 想された。また, 自分で育てた植物を披露する機会や周囲の人之 のコミュニケーションの場を求めて, 街路空間という開かれた空 間で植物栽培を始めた回答者むいることが明らかとなった。物理 的な効果を期待して植物栽培を始めた人の理由としては, 「犬猫 のフンや尿の対策として」が 7 人,「迷惑駐車防止のため」が 3 人, 「踏み荒らしの防止のため」が 1 人認められ，植物栽培によ り街路空間をきれいに保つことにより, フン害, 迷惑駐車や踏み 荒らしなどを防止することができると期待されていた。

図一 4 は, 植物栽培を始めたきっかけを年代別に示したもので ある。「日当たりを求めて」は, どの年代においても $30 \%$ 以上の 高い割合を示していた。1979 年以前から栽培を行っている回答 者の中では, 「日当たりを求めて」が最も多かった。1970 年代〜 1990 年代では，「栽培スペースがなかったため」という理由が 3 割以上と多くなっていた。1980 年代以降に植物栽培を始めた回 答者の中では, 「街路空間が殺風景だったから」が最も多くなっ た。これは 1980 年代以降, 都市開発に伴い, 街路空間を殺風景 と感じた回答者が栽培活動を始めたのではないかと考えられた。 このように, 時代の変化に伴い, 街路空間屯变遷し, 近隣住民の 街路空間に対する考え屯变化してきたと推測された。

\section{（4）植物の入手方法}

街路空間で利用している植物の入手方法については，「その場 所に植えるために購入した」が 88 人 (45\%) と回答者の半数を 占めた。また,「ほかの場所で栽培していたものを移動させた」 が 85 人 (43\%),「近所の人にもらった」が 66 人 (34\%),「どこ かに植えようと思って購入した」が 51 人 (26\%), 「自然に生え てきた」が 18 人（９％) となった。その場所に植えるために購 入した回答者は, 街路空間での植物栽培を植物購入時から念頭に 入れているものと推測された。他の場所で栽培していたものを移 動させた回答者は, 図一 4 のデー夕から見て, スペースや日当た りの問題により, 街路空間で植物を栽培するようになったと推測 された。その他の回答としては，「身内や知人にあらった」が 6 人,「店(生花店)の商品を置いている」が 2 人, 「あまっていた種

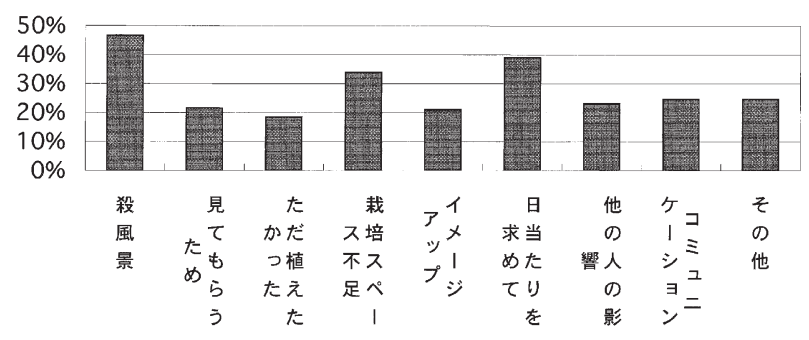

図ー3 植物栽培を始めた理由 $(N=195)$
を植えた」が 2 人などが挙げられた。街路空間での植物栽培は, 周囲の人と接する機会が多く，種子，株分けなどの方法による繁 殖や交換が多く行われていることが示された。

\section{（5）植物の管理について}

街路空間で栽培している植物への灌水頻度は,「2 日に 1 回未 満」が 95 人 $(47 \%), 「 2$ 日に 1 回以上」が 70 人 (35\%),「1日 に 1 回以上」が 10 人 ( $5 \%$ ) となった。「2 日に 1 回未満」の中で は「週に 3 回程度」が最む多く 32 人, 次いで「週に 1 回」が 20 人,「週に 2 回」が 18 人という結果となった。アンケートを実施 したのが冬期であり，その時期の回数を示した今回の灌水回数は 少ないと推測され，夏期であればより多くなったと思われる。

街路空間で植栽している植物への施肥の頻度は, 「年 4 回未満」 が 101 人（50\%）と最も多く，ついで，「年 4 回以上年 12 回未満」 が 25 人 (12\%)，「月 1 回以上」が 7 人 ( $3 \%)$ となった。「年 4 回未満」の中では, 「年に 2 回」が 45 人で最も多く,「年に 1 回」 は 31 人であった。また，「行っていない」という回答者む 58 人 （29\%）見受けられた。

植物栽培箇所の除草頻度は,「月 1 回以上月 4 回未満」が 99 人 $(49 \%), 「 月 4$ 回以上」が 15 人 $(7 \%)$,「月 1 回未満」が 10 人 （５％）となった。「月 1 回以上月 4 回未満」の中では,「月に 1 回」が 63 人と最む多かった。また, 草が気になった時, 適宜行 う回答者屯 8 人見受けられた。

街路空間で栽培している植物の植え替えについては，「植物が 枯れた時に植え替える」が 87 人（46\%）で，「花の時期に合わせ て植え替える」は 71 人（37\%）となった。街路空間での植物栽 培は栽培者が栽培を楽しむという側面と, 通行人が植物を見て目 を楽しませるという両面を持っているため, 植物が完全に枯れ人 前に曝される前に植え替えを行うのが望ましいと考えられていた。 花の時期に合わせて植え替えを行っていた人も 4 割弱見られ，今 後, このような回答者に影響され，時期にあった花を植える人が 増えてくることが期待できる。また，「植え替えを行ったことが ない」という人も 36 人（19\%）見られ，低木など植え替えの必 要が無いものを栽培していた回答者む含まれていた。

\section{（6）街路空間に対する認識}

植物栽培を行っている植樹枰㧍よびその周辺の空間を「公共の 空間である」と捉えていた植物栽培者が 127 人 (63\%), 「自宅の 庭のようなあの」と捉えていた回答者が 39 人 (19\%),「借地の ようなもの」と捉えていた回答者が 13 人 (6\%) 存在すること が明らかとなった。「自宅の庭のようなもの」と考えていた回答 者は, 他の 2 項目と比較し, 「庭」で植物栽培を行っている比率 が最む少なかった（図一 5 )。

街路空間抢よび歩道全域(以下，公有地)の利用に対する回答者 の考えは，「空間を有効に活用することができて良い」が 96 人 （48\%）で最も多く，「自分の土地ではないので気が引ける」 44 人 (22\%) の 2 倍以上を示していた。これら回答者は, 公有地に

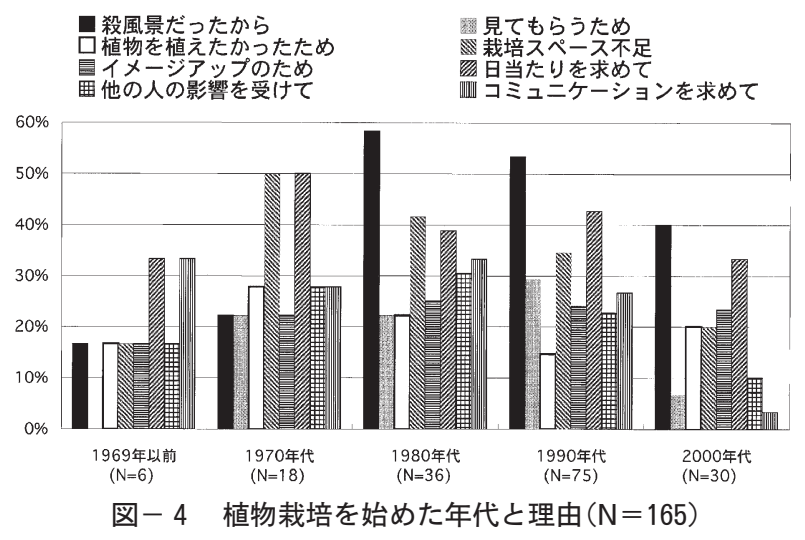


扔ける「不法占用行為」を, 土地の有効活用策の 1 つとして街路 空間に彩りを添えている行為之考え, 正当化しょうとする傾向が 認められた。また，「特に何屯感じていない」という回答者も 20 人 (10\%) 見受けられた。

\section{(7) 周囲との関わり}

街路空間で植物栽培をする際, 周囲の街並みとの調和をどの程 度考慮するかを尋齐たところ，「よく考える」が 17 人（10\%）, 「少し考える」が 52 人 (30\%)，「どちらともいえない」が 40 人 (23\%)，「あまり考えない」が 53 人 (30\%),「全く考えない」が 12 人（7％）となった。路線ごとに見てみると, 北山通南, 北 山通北, 白川通西, 下鴨本通西では, 「上く考える」,「少し考え る」という回答者が 6 割を超えていた。周囲の街並みとの調和に 対する意識は, 地域によって差が認められることが明らかとなっ た。どのような点に考慮しているかについては,「周辺の街並み の雾囲気之調和するか」が 38 人 (56\%), 「街路樹之調和するか」 が 29 人 (43\%), 「周辺の街並みと色が合うか」が 14 人 (21\%), 「周辺の建物と材質が調和するか」が 13 人（19\%）となっていた。

周囲の人がどのように評価しているかについて栽培者に自己判 断を求めた質問では, 「好評であると思う」が 93 人 (51\%),「ど ちらともいえない」が 36 人（20\%)，「好評ではないように思う」 が 2 人（1％）という結果となった。 5 割を超える人が自らの植 物栽培に自信をむって打り, 周囲の人々に好評であると考えてい た。一方，「分からない」とした栽培者も 52 人 (28\%) 存在し, 街路空間での植物栽培に対して周囲の評価が分からず戸惑ってい る様子が伺われた。

近隣住民や通行人との交流として，「手入れをしていると声を かけられる」が 142 人 $(76 \%)$,「植物の株分けなどを行っている」 が 57 人 (30\%), 「留守時に水やりをやってもらう」が 21 人 (11\%) と, 街路空間という多くの人が往来する空間で植物を栽 培することで，植物を通じて近所の人や通行人と交流をすること ができるということが明確に示された。植物栽培により街路空間 に执いてコミュニケーションの場を形成しているといえた。

\section{(8) 問題点と今後のあり方}

街路空間で植物栽培をする上で不安なこと・困っていることを 尋补たところ,「犬や猫の糞尿害に遭う」が 100 人 (57\%), 「鉢 を盗られてしまう」が 98 人 (56\%), 「自転車や通行人により植 物が荒らされる」が 93 人 (53\%), 「花を摘んでしまう人がいる」 が 70 人 (40\%) となった。栽培者は犬や猫の尿が直接植物にか かると枯死する可能性があるため困惑しているが，一方，植物栽 培を行わない犬や猫の飼主の中には, 犬猫の糞尿を有効な肥料之 勘違いしている者屯存在しており, このような意識の相違が問題 と考えられた。街路空間という公有地での植物栽培は, 周囲の人 とのコミュニケーションが楽しめるといった利点の一方で, この ような弊害が付随していることが明らかとされた。

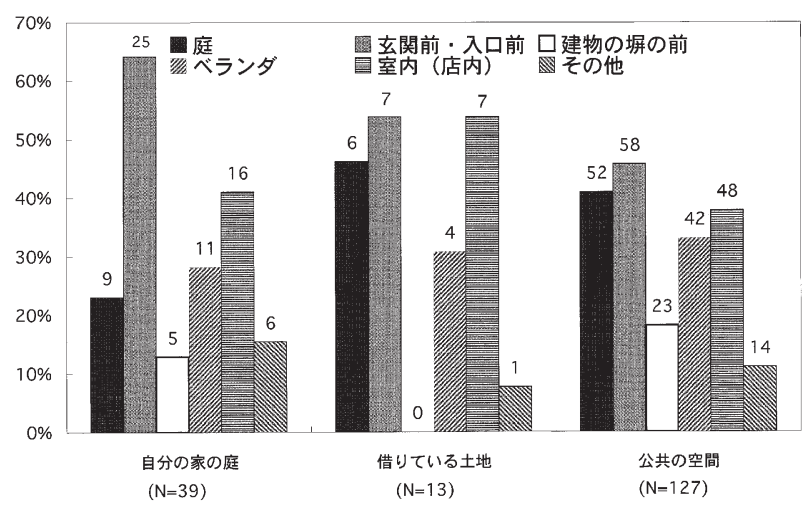

図- 5 街路空間の捉え方とその他の栽培場所 $(N=179)$
また今後，街路空間で植物栽培を行う上で行政に望むことは何 かという質問では，「街路空間での植物栽培を公認してほしい」 が 94 人 (67\%), 「苗や用土・肥料の援助をしてほしい」が 31 人 (22\%)，「植樹枰を正式に貸し出してほしい」が 20 人（14\%）之 なった。栽培者の心情としては, 無断で公有地を占用しているこ とに対して，多少の差はあるにしても良心のとがめがあるあの之 考えられ，気兼权なく栽培を行うためにも，行政による植物栽培 の公認を求める回答者が多く存在した。また, 植樹枡の貸し出し を望む回答者むいることから，栽培者の中には，土地を借りてで あ植物を栽培したいという欲求があると考えられた。

\section{4．通行人を対象としたアンケート結果 （1）回答者の基本情報}

2001 年 11，12 月に，京都府立大学学生ならびに生涯学習受講 者を対象として 564 部のアンケートを配布し，421 部の有効回答 を得ることができた（回収率 $74 \%$ )。回答者は, 男性が 171 人 (41\%)，女性が 222 人 $(53 \%)$ ，性別不詳 28 人（7\%）之，女性 の回答者がやや多くなった。年齢は，10 歳代が 44 人 (10\%)，20 歳代が 154 人 (37\%)， 60 歳代が 118 (28\%)， 70 歳代が 69 人 （16\%）となり，30 歳代（ 3 人)，40 歳代（ 7 人)， 50 歳代（15 人）の意見が極端に少なくなっているが，本論では，10 歳代・ 20 歳代の若い世代の意見と 60 歳代, 70 歳代の意見としてアンケー トの結果をまとめていくこととした。職業については，学生が 202 人 $(48 \%)$, 無職が 118 人 $(28 \%)$, 専業主婦が 50 人 (12\%) となって打り, そ机以外では, 会社員 ( 6 人), 自営業主・家族 従業員 ( 8 人), 無回答 (18 人), その他 $(10$ 人) となった。

\section{(2) 自宅での植物栽培の有無}

自宅で植物栽培を行っている回答者は，309人（73\%）となっ た。回答者には, 比較的自由な時間が多い 60 歳代, 70 歳代の人 が多く, 趣味として植物栽培を行っていたのではないかと考えら れた。自宅で植物を栽培している箇所としては，「庭」が 198 人 (64\%) と最む多く，「玄関前」が 172 人 (49\%)，「室内」が 154 人 (36\%) となっていた。

\section{(3) 自宅周辺の街路樹}

自宅に面した通り沿いに街路樹があるかを尋齐たところ，街路 樹があるとした回答者は 103 人（24\%）となった。街路樹のある 路線には, ビル，事務所や店舗などが建っていることが多く，住 宅地域を形成しているのは一部であったため, 自宅の近くに街路 樹があるあのの, 自宅に面した通りに植樹枡はないという回答者 が多かった。街路樹があるとした回答者のうち，街路空間で植物 栽培を行っていた回答者は，22人（ $5 \% ）$ のみであった。街路 空間での植物栽培を実際に行っている人は街路樹周辺に住んでい る人の中でもごく少数であるといえる。

\section{（4）街路空間での植物栽培の認知度}

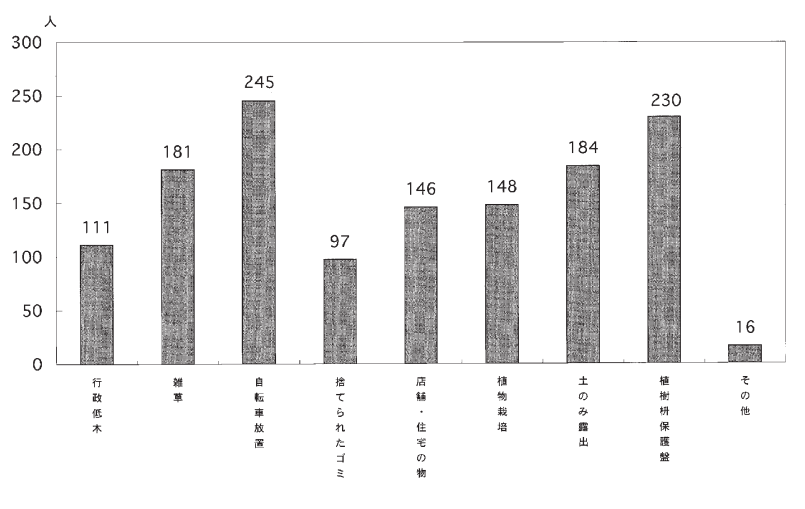

図 -6 目に付く植樹枡内の様子 
街路空間で植物栽培を行っていない回答者 400 人に対し, 街路 空間に抢ける植物栽培の事例を知っているか質問した結果，「上 く知っている」が 105 人 (26\%), 「知っている」が 171 人 （43\%）と，7割近くの回答者がその存在を認識していたことが 明らかとなった。また，街路空間を通行していて，よく目にする 植樹枡の様子を挙げてもらったところ, 図一6のようになった。 「植樹枡保護盤が設置されている」 250 人 (59\%) や「自転車が 置かれている」 245 人 (58\%) については, 半数を超える人がよ く目につくと挙げていた。60歳代, 70 歳代では, 「雑草が多く生 えている」 112 人 (26\%), 「近隣住民による植物栽培が行われて いる」 107 人 (25\%) が他の項目と比較して多くなっていた。

\section{（5）住民の街路空間との関わり}

街路樹との関わりについて ( i ) から ( v ) の項目に, a. 近隣住民 は街路空間に対しごの程度関わることが適当であるか, b. 自分を 近隣住民の立場においた時どの程度街路空間に関わっていこうと 考えるか, という 2 つの立場より全回答者に 5 段階の評価を求め た（図一 7 )。

（i ） 既存の街路樹・低木への水やりについて

a . 既存の街路樹や低木への水やりに関して，246人（58\%） が「するべきだ」「した方が良い」と回答した。行政側からも， 夏期には市民新聞10)等により街路樹への水やりを呼びかけており， 定期的な水やりに関しては地域住民で行ってもらいたいとの考え と合致していた。

b. 自分が付近に住んでいると仮定した時，「ぜひ行いたい」, 「どちらかといえば行いたい」という回答者は，204人（48\%） であった。前述において，「するべきだ」と答えた人に比べ， 10 \%下がった。しかし, 半数近い人が水やりについては行いたいと 考えていた。

(ii) 落ち葉の片付け

a . 秋期に街路樹の落ち葉を清掃することに関して, 323 人 （77\%）が「するべきだ」，「した方が良い」と回答した。アンケー 卜の自由記載欄には, 街路空間が落ち葉で覆われ見栄えが悪い, 側溝や樋が詰まる, 通行人の転倒などの危険があるなどの意見が 見受けられた。

b . 自分が落ち葉を清掃する立場に立った場合， 255 人 （61\%）の回答者が落ち葉の片付けを行いたいと考えていた。

(iii) 除草

a . 植樹枰内に生えてきた雑草の除草について, 252 人 （59\%）が「するべきだ」，「した方が良い」と回答した。落ち葉 の清掃に比べると少ないが, 自宅周辺の街路空間の除草を行った

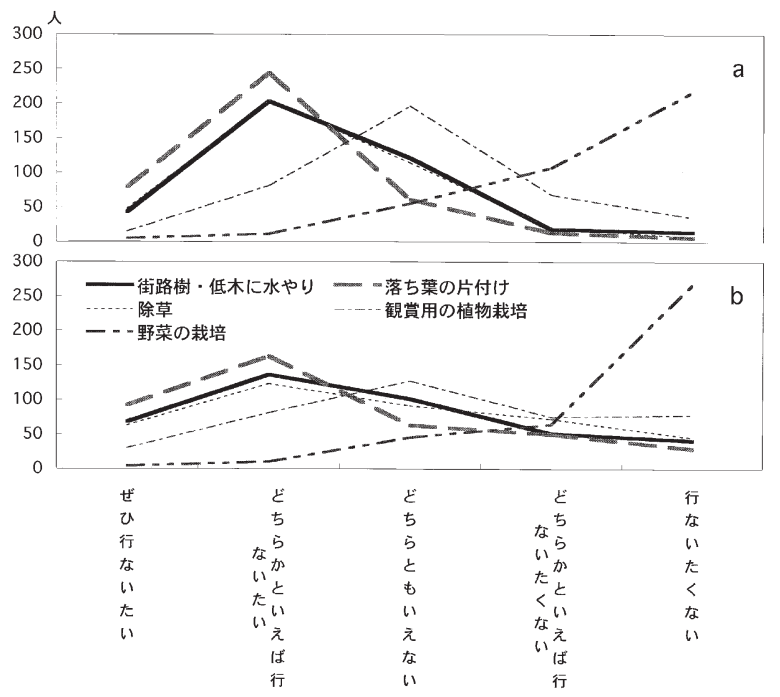

図- 7 近隣住民の望ましい街路樹との関わり方
方が良いと考えている人が 6 割程存在していることが明らかとなっ た。

b. 自分を行う立場に置いてみると，「ぜひ行いたい」，「どち らかといえば行いたい」と回答した回答者が 186 人（44\%）とな り，設問 a.の回答よりも減少した。「どちらかといえば行いたく ない」，「行いたくない」とした回答者が 117 人（28\%）となって 打り，行った方が良いと理解しながらも，自分では行いたくない という人が多いことが明らかとなった。

（iv） 観賞用の植物栽培

a. 観賞用の植物栽培に関しては，「どちらであ良い」が 196 人 $(47 \%)$ で半数を占めた。また，「ぜひ行いたい」，「行いたい」 と回答した人は 96 人 $(23 \%)$ にとどまり，「どちらでむ良い」と 答えた人の半数以下であった。

b. 観賞用の植物栽培に関しては，他の項目と異なり，自分が 行う立場になった場合，「ぜひ行いたい」，「行いたい」が 111 人 （26\%）と，設問 a の $23 \%$ と比較してわずかながら比率が大きく なった。

(v) 野菜の栽培

a．野菜の栽培に関しては，「するべきではない」，「しない方 が良い」と考える回答者が 324 人（77\%）となっていた。観賞で きる植物の栽培とは異なり, 野菜の栽培は個人が収穫して楽しむ という側面があるため，公有地を管理者の許可なく（以下，私的） 利用していると強く感じ, 反対する回答者の割合が一段之高くなっ たのではないかと推測された。

b. 自分が栽培を行う立場に立ったとしても「行いたくない」, 「どちらかというと行いたくない」が 331 人（78\%）と大半を占 めた。

\section{（6）街路空間での植物栽培に関する評価}

街路空間での植物栽培について, 以下の ( i )から ( v )の側面か ら 5 段階で評価してもらった。

（i） 街路空間を華やかにする効果

「植物栽培により街路空間が華やかになること」について, 「とても良い」，「良いと思う」とした回答者は 304 人（72\%）と なった。植物栽培によって殺風景な街路空間が華やかになること は，多くの人が歓迎しているといえる。

(ii） 空間の有効活用

「場所が有効に活用されること」に関して栽培活動の評価を求 めたところ，「とても良い」，「良いと思う」とした回答者が 243 人 (58\%) となった。6 割程の回答者が, 街路樹の周辺という有 効利用されていない空間を活用することに関して，良いことであ ると考えていた。栽培者へのアンケート回答をも参考にすると， 街路空間での植物栽培は, ただ単に有効利用されていない空間の 活用となるだけでなく, きれいに植栽することで, 自転車の放置 の防止, 犬や猫の糞尿の対策と屯なりうると考えられているよう である。

（iii）公有地における私的栽培

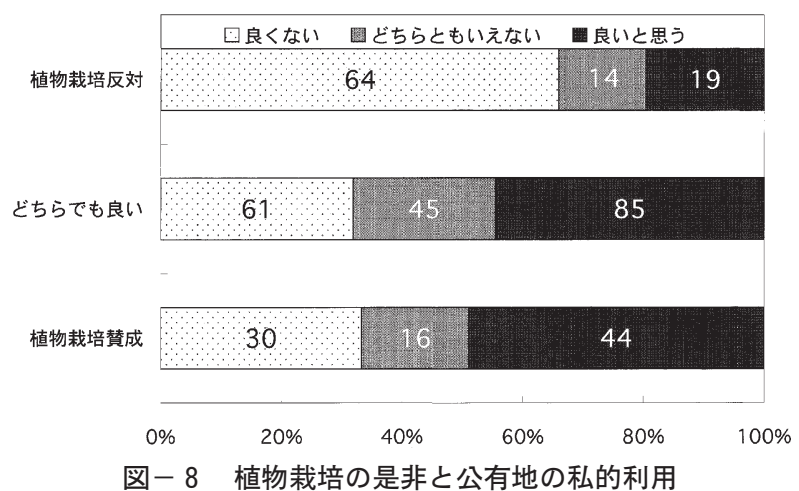


「公共の空間で私的に植物を栽培すること」についての是非を 尋齐たところ，「良くない」，「あまり良くない」との回答が 162 人 (39\%) となり,「別に良い」,「全く構わない」と回答した回 答者が 150 人 (36\%) と, ほぼ同じ割合であった。また, 街路空 間での植物栽培に反対している回答者の内, 公有地で私的に植物 を栽培するのは良くないと感じている回答者の割合が約 7 割を示 し, 賛成している回答者とどちらともいえない回答者に比べて高 かった（図一 8 )。植物栽培に賛成している回答者の中にも, 公 有地の私的利用に関しては良くないと感じている回答者が 3 割強 いることから，街路空間での植物栽培が 100\%私的な栽培になら ないようなシステムづくりが必要なのではないかと考えられた。

また，真鍋 ${ }^{11)}$ は，緑を足がかりにして自宅周辺の環境への関心 が高まり, 敷地境界を越えて地域を維持管理する行為や責任感覚 が波及的に増大するという効果を指摘しており, 公有地での地域 住民の自発的な意志による植物栽培の効用を認め, その意志を尊 重した街路空間づくりに活用していくべきではないかと考えられ た。そのためには, 行政によるバックアップが必要となるのでは ないかと思われた。

\section{（iv）公有地に打ける私物の放置}

「栽培に関係しない私物を置くこと」についての是非を尋ねた ところ,「良くない」,「あまり良くない」とした回答者が 334 人 （79\%）となった。植物栽培を賛成している 89 人の回答者の中で, 私物を置くことの是非を質問したところ，79人（89\%）の回答 者が栽培に関係しない私物を置くことに関して, 反対という姿勢 を見せた。このことから, 街路空間での植物栽培に賛成している 人であっても, 植物栽培に関係しない私物が街路空間に放置され ることに関しては, 快く思っていないということが判明した。

（v）きれいに栽培

「きれいに栽培されていたら植物栽培を行っても良いか」と尋 水たところ，「とても良い」，「良いと思う」とした回答者が 265 人 $(63 \%)$ となった。6 割以上の回答者がきれいに栽培されてい たら, 植物栽培を認めるという姿勢を見せ, 今後の街路空間での 栽培活動に抢ける 1 つの方向性が示されたといえよう。

\section{（7）望まれる植樹枅のあり方}

街路樹の下の地上部の望ましい状態を尋㸚たところ,「花の咲 く植物の植えられている状態」が 229 人 (56\%), 「植樹枰保護盤 が設置され歩道との段差のない状態」が 180 人 (44\%), 「常緑の 植物が植えられている状態」が 152 人（37\%）となった。花の咲 く植物を求めている回答者が半数を超えた一方で, 歩道との段差 のない状態を求めている人も 4 割以上認められ, 植物栽培によっ て街路空間を彩ることを考えると同時に, 段差のない街路空間づ くりを行う必要性が示された。また, 「行政による低木の植えら れている状態」が 97 人 (24\%),「何も手を加えていない状態」

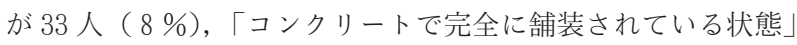
あ 27 人 $(7 \%)$ 見受けられた。

\section{（8）望まれる植物栽培形態}

住民が街路空間で植物栽培をする際, どのように栽培されるこ とを望むかを尋ねたところ，「街ぐるみで周辺の街並みに調和し た植物を栽培し, 統一感を持たせるようにする」が 170 人 (43\%) で 4 割以上に支持され, 街ぐるみで植物栽培を行い, 統 一感を持たせるようにすることが望まれていた。ついで「個人・ 各家庭で栽培してもらい, 様々な植物を楽しめるようにする」が 54 人 (14\%), 「街ぐるみでいろいろな植物を栽培し, 様々な植 物を楽しめるようにする」が 51 人 (13\%)，「個人・各家庭に栽 培は任せるが, 植える植物に統一感を持たせるようにする」が 42 人 $(11 \%)$ となった。また， 55 人 (14\%)ではあるが，「植物栽 培に反対」という回答者もいることが判明した。

\section{5.まとめ}

京都市内の様々な用途地域の街路空間で植物栽培を行っていた 栽培者を対象としたアンケート調査では，8割以上の回答者が植 物を栽培することが好きであると回答し，公共の空間であるとい う認識を持ったうえで, 自らの栽培行為が街路空間に彩りを添え ていると確信し，活動を行っていた。しかし，街路空間を自宅の 庭のように捉えていた栽培者む 2 割存在する一方, 自分の土地で はない場所に抢ける植物栽培に良心のとがめを感じている栽培者 あ 2 割存在していることが明らかとなった。植物栽培は, 街路空 間の環境を向上させるだけにとどまらず，自分の育てた植物を周 囲の人に披露することや，植物を介して周囲の人々とコミュニケー ションを図る効果が認められた。

通行人を想定した被験者へのアンケート調査では， 7 割以上の 回答者が地域住民によって栽培されている植物によって街路空間 が華やかになることを肯定的にとらえており，栽培者と同様の見 解を持つことが示された。逆に, 街路空間という公共の空間を菜 園として私的に利用することなどに対しては，快く思わない回答 者が 7 割強存在していることが認められた。そのことから, 栽培 者である街路樹近隣住民の節度ある栽培活動によって, 通行人之 なりうる近隣住民の理解を得ることもできると考えられた。また， 自らむ草花栽培を行いたいという通行人ああり, 栽培を通じてコ ミュニケーションが生まれるとの回答む示されたことから, 今後, 街路樹周辺での植物栽培に参加する住民の裙野を広げる可能性が 推測された。

本研究結果から, 街路樹周辺で住民によって栽培されている植 物が, 街の景観を向上させる緑の一翼を担っていることが示され たといえよう。また, 街路樹周辺での植物栽培の公認や土地の提 供などを求める声も少なくなかったことから, 今後, 行政がその ような支援に着手すれば，街路樹周辺での植物栽培がより普及し， 良好な街路空間の創造の一助となりうるのではないかと推測され た。

\section{引用文献}

1) 長沼真美・上甫木昭春（2003）：神戸市の街路空間における沿道住民 による「勝手花壇」の実態と住民意識に関する研究：ランドスケープ 研究 66 (5), 819-824

2 ) 篠塚香里・横張真・栗田英治・渡辺貴史 (2003)：密集市街地に打け る錸植えの緑の配置と形態：ランドスケープ研究 66(5), 825-828

3) Assenna TODOROVA • Shoichiro ASAKAWA • Tetsuya AIKOH (2002): Attitudes Towards Street Flowers in Sapporo: J.JILA65 (5), $717-722$

4 ）下村孝・小松さち恵・大藪崇司（2004）: 京都市における街路樹植枡 周辺での住民による植物栽培の実態：人間・植物関係学会雑誌 $3(2)$, 6-11

5 ）京都市建設局水と緑環境部緑地管理課編（2002）：京都市公園街路樹 配置図 $(1 / 25,000)$

6 ) 京都市建設局水之緑環境部緑地管理課編（1999）: 京都街路樹ガイド

7 ）加藤五郎（1994）：京都の公園・街路樹物語り：京都造園惥談会, 1929

8 ）権孝姃・松尾英輔・高橋博之（2001）：専用住宅の門外または玄関前 の植物の配置状況について：ランドスケープ研究 64 (5), 375-378

9 ) 高橋ちぐさ・下村孝 (2002)：雑誌・書籍の出版動向及び記事内容か ら見たガーデニングブームの実態：ランドスケープ研究 65(5), 397400

10）京都市広報課（2003）：市民新聞 8 月 1 日号：京都市印刷物第 151073 号, 10

11）真鍋千恵子（1998）：下町の緑の実態上効用〜街と人とを緑がつなぐ： ランドスケープ研究 62(1)，42-44 